\title{
Mapping Peatland Fires Using a Drone Equipped with a Thermal Camera
}

\section{赤外線カメラ搭載型ドローンを用いた泥炭火災の地図化}

\author{
Taishin KAMEOKA*, Osamu KOZAN ${ }^{* *, * * *}$, Sunawiruddin $H A D I^{* * * *}$ \\ ASNAWI**** and HASRULLAH** \\ 亀岡 大真・甲山治・スナウィルディン ハディ

$$
\text { アスナウィ・ハスルーラ }
$$

和文概要：インドネシアでは2015年に約 86 万 ha の泥炭地で火災が起きたことで, 大量の二酸化炭素が排出された。泥炭 復興庁を設立し，対策が取り組まれているが，2019年にも多数の火災発生が報告された。火災対策が進まない理由として， 泥炭火災が土中に潜り込み，目視による火災の位置や規模の特定をすることが困難であることが挙げられる。このような 状況を改善するために，泥炭火災の早期発見と規模の特定をすることができる新しい技術が必要である。本研究では2019 年 9 月にインドネシアの泥炭火災地で赤外線カメラを搭載したドローンを用いて，泥炭火災の検知や規模の特定を可能に する泥炭火災図を作成した。本手法が今後の泥炭火災対策や研究に役立つ基礎的な研究になることを期待している。

\section{Introduction}

Indonesia is rich in carbon stock, having an estimate of 22.5 million hectares of peatland (Hooijer et al., 2006) and 57.4 billion tons of carbon storage (Page et al., 2011). However, large peatland fires occurred between June and October 2015 in Indonesia, burning approximately 860,000 hectares of peatland (World Bank 2016) and releasing large quantities of soil carbon. In Indonesia, the Peatland Restoration Agency was established in 2016 to protect the peatland areas (Myrna 2016). However, peatland fires occurred frequently in 2019 (Gunawan 2019 ; BBC 2019), which indicates that the problem has not been solved. These fires are invisible to the

* Graduate School of Asian and African Area Studies, Kyoto University

** Research Institute for Humanity and Nature

*** Center for Southeast Asian Studies, Kyoto University

****JICA Partnership Program

「写真測量とリモートセンシング」VOL. 59, NO. 5, 2020

$-214-$ naked eye because they burn underground and are not visible from the surface, which causes serious problems in the fields because it is difficult to completely extinguish them. In addition, some fires cannot be detected until they increase because they occur in places where people cannot access. However, using drones equipped with thermal cameras can be an effective method to identify and prevent peatland fires. Burke et al. reported the use of drones equipped with thermal cameras for detecting peatland fires in an artificial setting (Burke et al., 2019). In addition, drones can easily access and detect peatland fires from the sky in locations with limited accessibility to people. They can also take photos of the fire scene. Thus, they enable easy and early detection of peatland fires and facilitate their extinguishing. However, further research is required to study the efficiency and methods of implementation of drones equipped with thermal cameras for detecting peatland fires. Therefore, in this study, an orthomosaic map was constructed to visualize the position and scale of peatland fires in nature to contribute to their prevention. 


\section{Methods}

\subsection{Study Area}

The study was conducted on a farmland located on a peatland in the province of Riau in Indonesia $\left(0^{\circ} 21^{\prime} 58.42\right.$ ”N $\left.101^{\circ} 52^{\prime} 3108^{\prime \prime} \mathrm{E}\right)$. The monthly rainfall in this location was less than $2.6 \mathrm{~mm} /$ day (Figure 1). According to the nearest weather station in Pekanbaru City, the rainfall was only $1.5 \mathrm{~mm}$ between August 31 and September 21, 2019. This amount is less than the typical rainfall over three weeks (BMKG DATA ONLINE). Thus, during this time, the peat soil was likely dry, and consequently peatland fires had been burning underground in the study area since the end of August, developing into serious surface fires that had to extinguish on September 17, 2019.

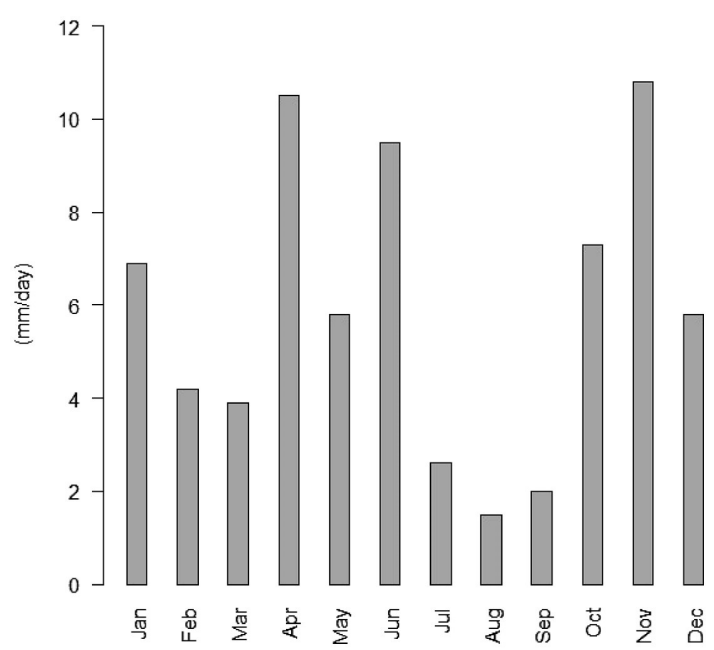

Figure 1. Average monthly rainfall in Pekanbaru City in 2019

\subsection{Aerial Photography (Acquisition of RGB and Thermal Infrared Images)}

The observation area was 1 ha $(80 \mathrm{~m} \times 131 \mathrm{~m}$, Figure 2-a). On September 13, 2019 from $17: 25$ to $17: 56$, two drones (DJI Phantom4 Pro (P4P) and Inspire 1) were used to take RGB and thermal infrared images of the observation site. Agisoft Photoscan Professional Version 1.4.2 (Agisoft LLC., Rus- sia) was used to convert these images into orthoimages. RGB images were obtained by the P4P drone. The overlap and sidelap rates were set to more than $80 \%$ and $60 \%$, respectively, as recommended by the Photosacan software (Agisoft LLC., 2018). In addition, as the smoke from the peatland fire could have blocked the view of the ground when taking the pictures. Therefore, both the overlap and sidelap rates were set to $85 \%$ on the $\mathrm{P} 4 \mathrm{P}$, and the flight altitude was set to $50 \mathrm{~m}$ (resolution $1.36 \mathrm{~cm} /$ pixel).

Thermal infrared images were obtained using a Zenmuse XT thermal infrared camera mounted on the Inspire 1. Dillen et al. reported errors when processing thermal imagery using the structurefrom-motion method with Photoscan because they were using a low overlap rate and low resolution (Dillen et al., 2016). The resolution of the Zenmuse $\mathrm{XT}$ is lower than that of the $\mathrm{P} 4 \mathrm{P}$, and the temperature of peatland fires constantly changes. Accordingly, the overlap and sidelap rates of the Inspire 1 were set at $90 \%$, which is higher than the rates of the $\mathrm{P} 4 \mathrm{P}(85 \%)$, to create a sufficiently accurate peatland-fire map. In addition, the flight altitude was set to $50 \mathrm{~m}$ (resolution $6.3 \mathrm{~cm} /$ pixel) to collect higher-resolution images and prevent the spread of peatland fires by the wind blowing from the propellers of the drone.

The Zenmuse XT has high and low gain modes. The range of the high and low gain modes are -25 ${ }^{\circ} \mathrm{C}$ to $135{ }^{\circ} \mathrm{C}$ and $-40{ }^{\circ} \mathrm{C}$ to $550{ }^{\circ} \mathrm{C}$, respectively. Peatland fires burn at a low temperature (Atwood et al., 2016) and cause the soil surface above them to reach temperatures higher than $50{ }^{\circ} \mathrm{C}$ (Burke et al., 2019). The high-gain mode covers a smaller temperature range but is more sensitive to temperature differences than the low gain mode. Thus, the high -gain mode was chosen in this study to correctly detect the position and scale of peatland fires, including low-temperature fires.

\subsection{Data Processing}

The RGB and thermal orthoimage were con- 

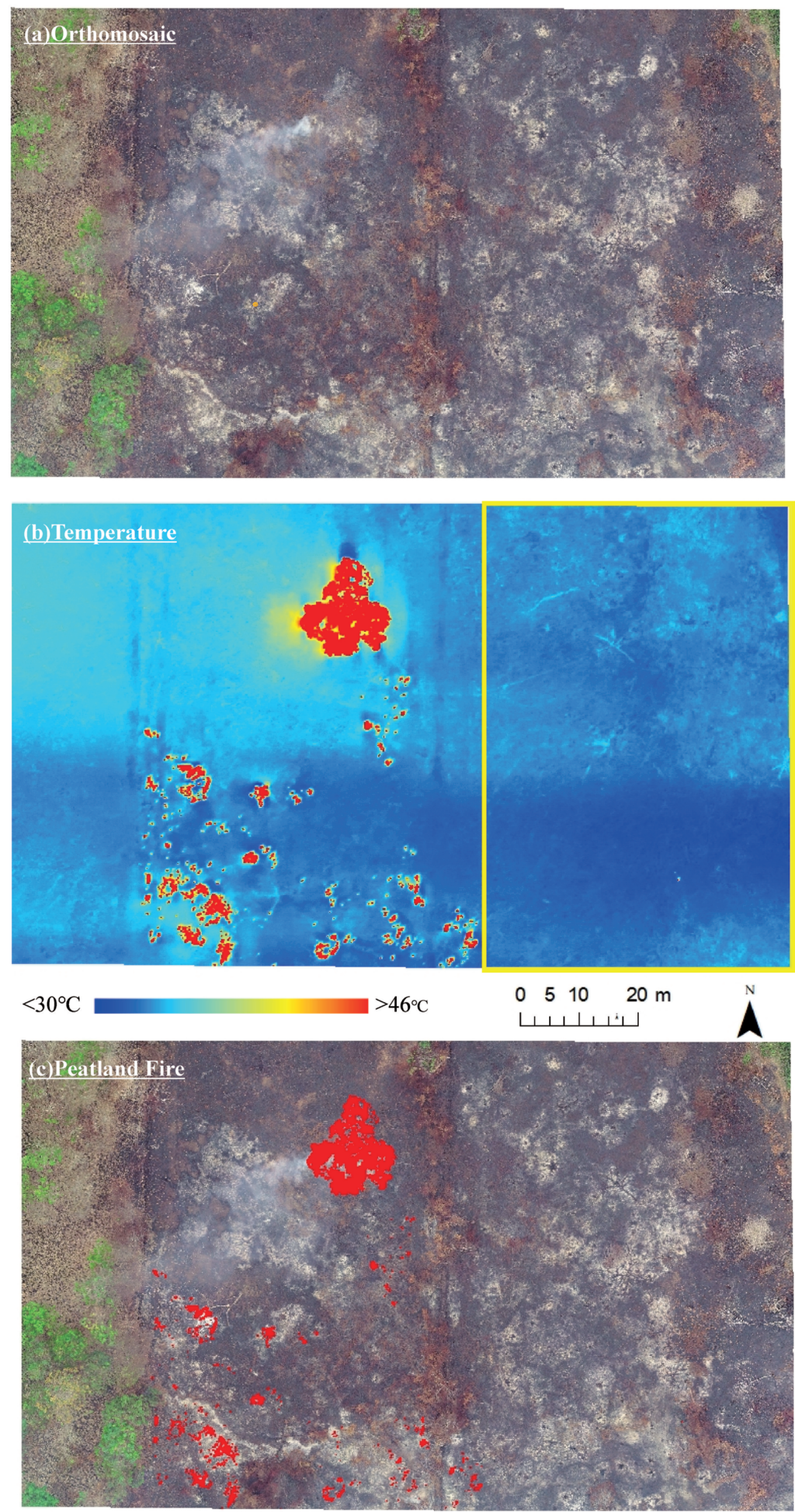

Figure 2. The map of drones at the study site (Sep 13). (a) Orthomosaic map and (b) temperature map were made by photos from the P4P and Inspire 1 equipped with the Zenmuse XT, respectively. (c) Peatland Fire map was combined with a map of (a) and (b). There was no fire in the area enclosed by the yellow line in (b) except a small hotspot. 
structed using 125 and 508 images, respectively. The collected photos were processed using the Photoscan 3D modeling software. This software performs automatic mosaicked processing of drone images, which involves aligning individual photos and generating mosaicked orthorectified imagery. In this study, the software was also used to generate mosaicked thermal imagery. The processing parameters were set to the "high" settings for the alignment process. Since there are less thermal 3D points than digital 3D points (Akcay et al., 2016), the key point and tie point limits were set to 0 to increase the number of points. A value of 0 means that there is no upper limit for each point limit. Next, the unreasonable points that appeared to be misaligned were manually deleted during the visual interpretation. The camera alignment was also optimized. In addition, dense cloud generation was processed first followed by mesh generation. Finally, the orthomosaic was generated using the mesh as the surface data, with the blending mode set to "mosaic." For the thermal imagery, the data was collected in the original format of the digital number (DN) value; thus, after mosaic processing, the following formula (obtained from Iizuka et al., 2018) was used to convert the data into absolute temperatures:

$T=0.04 \times D N-273.15$

where $\mathrm{T}$ is the temperature in degrees Celsius and $\mathrm{DN}$ is the original value observed in the image. The data were further analyzed using the converted absolute temperature. A temperature map (Figure 2 -b) was generated after this process by georeferencing the thermal orthoimages to the RGB ones using Arc Map 10.6. The map shows the locations, scales, and temperatures of the fires.

\subsection{Accuracy of the Soil Surface Temperature}

Next, the accuracy of the soil surface temperature was recorded using Zenmuse XT. These data were compared to the soil surface temperature measured by a thermocouple thermometer (A\&D

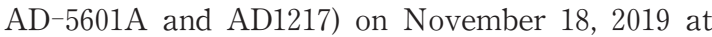

three peatland hotspots in Palangka Raya City, Central Kalimantan, Indonesia and at ten peatland spots with no fires on August 13, 2020 in Tanjung Leban village, Riau, Indonesia. Thirteen $40^{-} \mathrm{cm}$ plots were constructed, and their average temperatures were measured using a thermocouple thermometer and thermal images taken at an altitude of $50 \mathrm{~m}$. The average of the temperatures measured using Zenmuse XT was calculated from nine thermal images obtained in Palangka Raya City and a thermal orthomosaic image obtained in Tanjung Leban. The temperature of the thermocouple thermometer was regarded as the real soil surface temperature. Each measurement with the thermocouple thermometer was used eight points or more in each plot to calculate the average temperature.

\section{Result}

\subsection{The Temperature Threshold of the Soil Surface above Peatland Fires}

The temperature map (Figure $2-b$ ) enabled the detection of the thermal gradient at the study site. The soil surface temperatures were measured at 2587 points within the observation area (Figure 2) to determine the temperature threshold of the soil surface above peatland fires. In Figure 2-b, 1445 points enclosed by the yellow polygon determined normal soil surface temperatures (with no fires), except a small hotspot which was less $0.05 \mathrm{~m}^{2}$. The average, maximum, and minimum temperatures were $32.5{ }^{\circ} \mathrm{C}, 34.9{ }^{\circ} \mathrm{C}$ and $30.2{ }^{\circ} \mathrm{C}$, respectively. The normal temperatures were found to be less than 35 ${ }^{\circ} \mathrm{C}$ at the time of measurement (Figure 3 ; yellow polygon area).

The temperature threshold of the soil surface above peatlands was determined using the histogram of the soil surface temperature (Figure 3). A peak and trough were observed on the histogram just before a soil surface temperature of $46{ }^{\circ} \mathrm{C}$, which is a $10{ }^{\circ} \mathrm{C}$ higher than the maximum temperature of the area no fires $\left(34.9^{\circ} \mathrm{C}\right)$. Therefore, in this study, it was hypothesized that the temperature 


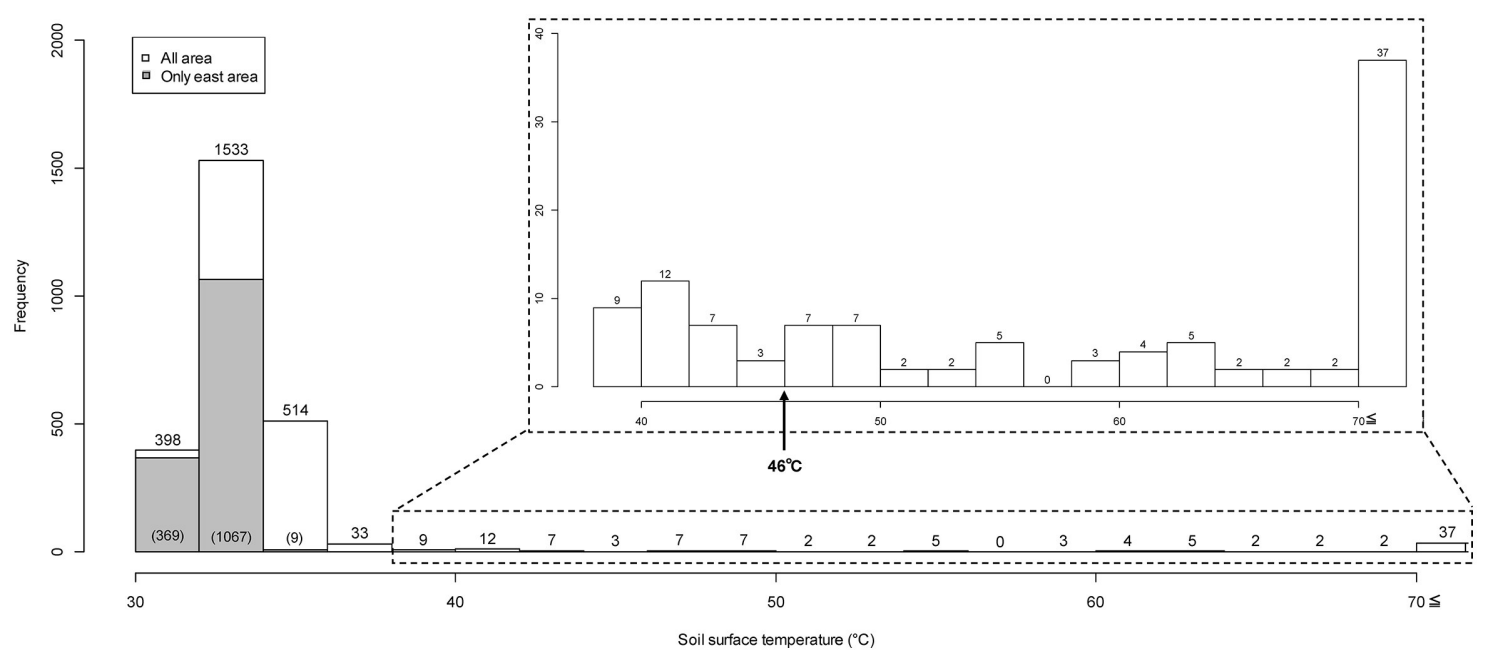

Figure 3. Histogram of value of soil surface temperature on obsearvation area of all and yellow polygon (Figure 2-(b)). The number of points of the yellow polygon area are used parenthesis. There were no points more than 35 ${ }^{\circ} \mathrm{C}$ in yellow polygon area. The number of points of soil surface temperature which was $70{ }^{\circ} \mathrm{C}$ or more is 37.

threshold of the soil surface above peatland fires is $46{ }^{\circ} \mathrm{C}$.

\subsection{Detection of Peatland Fires}

The detection of peatland fires using an RGB map (Figure 2-a) was as difficult as their detection with the naked eye. However, the temperature map (Figure $2-\mathrm{b}$ ) enabled the fire detection, even fires burning below the soil. The section on the temperature map with fires was overlaid onto the RGB map using Arc GIS to create a peatland-fire map (Figure $2-\mathrm{c}$ ). This map can easily detect the position and scale of peatland fires. The area with peatland fires in the observation site was found to be approximately 0.02 ha.

\subsection{Accuracy of the Soil Surface Temperature}

The average soil surface temperature determined by the thermocouple thermometer at each plot ranged from $34.8{ }^{\circ} \mathrm{C}$ to $227{ }^{\circ} \mathrm{C}$ (Table 1). The average temperature obtained using the thermal camera at each plot ranged from $36.0{ }^{\circ} \mathrm{C}$ to $152{ }^{\circ} \mathrm{C}$ (Table 1 ). The maximum temperature difference within one of the plots at a temperature higher than $135^{\circ} \mathrm{C}$ was 75 ${ }^{\circ} \mathrm{C}$, which was not useful in measuring temperatures outside the temperature range of high gain mode.
However, the average temperature difference was $2.7^{\circ} \mathrm{C}$ at the other plots, which is within the range of

Table 1. Validation of soil surface temperature recoded by the thermal camera and by thermocouple thermometer.

\begin{tabular}{cccc}
\hline No*1 & $\begin{array}{c}\text { Thermal } \\
\text { Camera }\end{array}$ & $\begin{array}{c}\text { Thermocouple } \\
\text { Thermometer }\end{array}$ & $\begin{array}{c}\text { Temperature } \\
\text { Gap }\end{array}$ \\
\hline 1 & 39.9 & 39.4 & 0.5 \\
2 & 37 & 36.6 & 0.4 \\
3 & 38.8 & 35 & 3.8 \\
4 & 42.4 & 37 & 5.4 \\
5 & 40.9 & 36.8 & 4.1 \\
6 & 37.8 & 35.8 & 2.0 \\
7 & 36.6 & 36.6 & 0 \\
8 & 36.1 & 36 & 0.1 \\
9 & 36 & 34.8 & 1.2 \\
10 & 38.4 & 35.4 & 3.0 \\
11 & 82 & 92 & -10 \\
12 & 102 & 104 & -2 \\
\hline \multicolumn{5}{c}{ Average Temperature Gap } \\
\hline (No. 1 to No. 12) & & 2.7 \\
\hline 13*2 & 152 & 227 & -75.0 \\
\hline
\end{tabular}

*1. No. 1-10 were located in Tanjung Leban village Unit : ${ }^{\circ} \mathrm{C}$

*1. No. 11-13 were located in Palangka Raya city

*2. Excluding No. 13 as a parameter of average temperature gap because the temperature of No. 13 was outside the temperature range of high gain mode. 
the high gain mode. At a comparatively high soil surface temperature, a negative temperature difference was obtained between the temperature measured at the soil surface and that measured using the thermal camera. On the other hand, the temperature differences between them were positive at a low soil surface temperature (Table 1 ).

\section{Discussion}

The accuracy test showed an average temperature difference of $2.7^{\circ} \mathrm{C}$ in 12 plots, which is within the range of the high-gain mode (Table 1 ). It is difficult to obtain an exact measure of the soil surface temperature. However, the position and scale of the peatland fires could be detected when a suitable threshold is set for their temperatures, which is sufficiently higher than the normal soil temperature. The results indicate that the normal soil temperature ranges from 30 to $34{ }^{\circ} \mathrm{C}$ (Figure 3 ). In addition, a considerable area was found to have a temperature of more than $46{ }^{\circ} \mathrm{C}$, which is significantly different from the normal soil temperature, which indicates the fire effects in this area. Therefore, in this research, a threshold of $46{ }^{\circ} \mathrm{C}$ is suitable to visualize the positions and scale of peatland fires, which cannot be detected by the naked eye. In fact, the $46{ }^{\circ} \mathrm{C}$ threshold was used as the peatland-fire temperature, and the peatland-fire map (Figure $2-\mathrm{c}$ ) shows the locations of the peatland fires within the observation area, even in cases with fires burning under the soil. This map provides information on fire locations, which enables their rapid extinguishing. Therefore, this method is more useful for detecting the position and scale of peatland fires in the field than conventional methods, involving visual detection.

However, the accuracy of peatland-fire maps strongly depends on the threshold of the peatlandfire. This threshold should have different values at each study site because the soil surface temperature is constantly changing. Therefore, the threshold of $46{ }^{\circ} \mathrm{C}$ is not always applicable to detect peatland fires in any places. This will be studied in future research. We expect that using a drone equipped with a thermal camera can form the foundation of future social activities and academic research on improving peatland-fire detection and responses.

\section{Acknowledgment}

These research activities are supported by the JICA Partnership Program "Restoration of Peatland Ecology and Livelihood Improvement through Rewetting and Revegetation toward the Prevention of Peat Fires" and Research Institute for Humanity and Nature (RIHN) under the Tropical Peatland project (No. 14200117). We thank the Center for the International Cooperation in Sustainable Management of Tropical Peatlands (UPT CIMTROP) at the University of Palangka Raya for supporting us in conducting accuracy testing for the temperature for peatland fires. This research was funded by RIHN and supported with equipment purchase by a Sasakawa Scientific Research Grant from The Japan Science Society.

(受付日2020.5.27, 受理日2020.9.7)

\section{References}

Agisoft L.L.C., 2018. Agisoft Photoscan User Manual Professional Edition, Version 1.4. https:// www.agisoft.com/pdf/photoscan-pro_1_4_en.pdf (accessed April 6, 2020).

Akcay, O., Erenoglu, R.C., Erenoglu, O. 2016. Correction and densification of UAS-Based photogrammetric thermal point cloud. International Archives of the Photogrammetry, Remote Sensing and Spatial Information Sciences - ISPRS Archives, 41(7), 163-166.

Atwood, E.C., Englhart, S., Lorenz, E., Halle, W., Wiedemann, W., Siegert, F., 2016. Detection and characterization of low temperature peat fires during the 2015 fire catastrophe in Indonesia using a new high-sensitivity fire monitoring satellite sensor (FireBird). PLoS ONE, 11(8), 1-25.

BBC., 2019. Forest fires: Are they worse than in 
previous years? https://www.bbc.com/news/ world-49515462 (accessed Oct 15, 2019)

Burke, C., Wich, S., Kusin, K., McAree, O., Harrison, M., Ripoll, B., Longmore, S., 2019. Thermal -drones as a safe and reliable method for detecting subterranean peat fires. Drones, 3(1), pp.23.

Dillen, M., Vanhellemont, M., Verdonckt, P. ; Maes, W.H. Steppe, K., Verheyen, K., 2016. Productivity, stand dynamics and the selection effect in a mixed willow clone short rotation coppice plantation. Biomass Bioenergy, 87, 46-54.

Gunawan, J. 2019. Beyond Indonesia forest wildfires 2019. Public Health of Indonesia, 5(3), 71-72.

Hooijer, A., Silvius, M., Wösten, H., Page, S., 2006. PEAT- $\mathrm{CO}_{2}$ : assessment of $\mathrm{CO}_{2}$ emissions from drained peatlands in SE Asia. Delft Hydraulics Report Q3943.
Iizuka, K., Watanabe, K., Kato, T., Putri, N.A., Silsigia, S., Kameoka, T., Kozan, O., 2018. Visualizing the spatiotemporal trends of thermal characteristics in a peatland plantation forest in Indonesia: Pilot test using unmanned aerial systems (UASs). Remote Sensing, 10(9).

Myrna, A.S. 2016. Peatland Restoration in In donesia. https://www.env.go.jp/earth/cop/cop22/ common/pdf/event/11/02 presentation1.pdf (accessed March 16, 2020)

Page, S.E., Rieley, J.O., Banks, C.J., 2011. Global and regional importance of the tropical peatland carbon pool. Global Change Biology, 17, 798-818.

World Bank., 2016. The cost of fire: An economic analysis of Indonesia's 2015 fire crisis. $2016 \mathrm{Feb}$; Indonesia Sustainable Landscape Knowledge Note. 1. 1 